\title{
Efektifitas Program Pelatihan Berbasis Kompetensi Pada Unit Pelaksana Teknis Daerah Balai Latihan Kerja di Kabupaten Subang
}

\author{
Iwan Henri Kusnadi \\ Fakultas Ilmu Administrasi Universitas Subang \\ iwanhenri01@gmail.com
}

\begin{abstract}
Abstrak
Tujuan penulis mengadakan penelitian ini adalah untuk mengetahui efektivitas program pelatihan berbasis kompetensi pada Unit Pelaksana Teknis Daerah Balai Latihan Kerja di Kabupaten Subang. Hasil penelitian yang berdasarkan kepada hasil wawancara dan observasi langsung, dengan demikian hipotesis yang penulis ajukan yaitu "Efektivitas Program Pelatihan Berbasis Kompetensi pada Unit Pelaksana Teknis Daerah Balai Latihan Kerja di Kabupaten Subang" ditentukan oleh faktor-faktor Produktivitas, Kualitas, Ketepatan Waktu, Putaran Waktu, Penggunaan Sumber Daya dan biaya diperoleh kesimpulan bahwa efektivitas program pelatihan berbasis kompetensi pada Unit Pelaksana Teknis Daerah Balai Latihan Kerja di Kabupaten Subang belum efektif, karena ada beberapa hal yang perlu ditingkatkan yaitu peningkatan sarana dan prasarana pelatihan serta penambahan sumber daya fungsional instruktur.
\end{abstract}

Kata Kunci : Efektivitas, Kompetensi, Kinerja Program

\begin{abstract}
The purpose of the authors conducted this study was to examine the effectiveness of competency based training programs in the regional technical implementation units of vocational training centers in Subang Regency. The research result of "Effectiveness of competency based training programs in the regional technical implementation units of vocational training centers in Subang Regency" district is determined by the factors of productivity, quality, timeliness, cycle time, use od resources and costs is concluded that the effectiveness of competency based training programs in UPTD BLK Subang district has not been effective, because there are some things that need to be improved, namely improvement of training facilities and the addition.
\end{abstract}

Keywords : Effectiveness, Competence, Program Performance 


\section{Pendahuluan}

Dalam rangka penyelenggaraan publik yang baik guna memenuhi kebutuhan yang diinginkan oleh masyarakat, pemerintah daerah sebagai penyelenggara pelayanan publik di lingkup daerah diberikan wewenang otonomi. Kewenangan otonomi memiliki pengertian yakni wewenang mengatur serta mengurus sendiri urusan pemerintahan dan kepentingan masyarakat daerahnya sendiri (daerah otonomi). Hal ini sesuai dengan azas otonomi daerah seperti yang tertuang pada UU No.23 Tahun 2014. oleh karena itu, pemerintah sebagai salah satu komponen yang bertanggung jawab mempersiapkan sumber daya manusia yang berkualitas, dengan berbagai cara di bidang ketenagakerjaan.

Namun hal yang sering terjadi saat ini adalah banyaknya penduduk usia kerja yang tidak semuanya dapat memperoleh keterampilan dan keahlian tertentu dari pendidikan formal. Banyak yang ingin melanjutkan sekolah tetapi tidak dapat melanjutkan karena terhambat biaya. Dari permasalahan tersebut berakibat banyaknya pemuda yang tidak melanjutkan sekolah. Akhirnya mereka berusaha untuk mendapatkan pekerjaan namun tidak semuanya dapat terserap dalam lapangan kerja. Hal ini di karenakan kurangnya pendidikan dan keterampilan serta keahlian yang dimiliki. Oleh karena itu, penyiapan tenaga kerja terampil dan ahli melalui pendidikan dan pelatihan kerja yang tepat dan terarah sangat di perlukan.

Tuntutan dunia kerja akan tenaga kerja terampil mendorong pencari untuk mengikuti pendidikan dan pelatihan kerja nonformal untuk menambah keterampilan dan keahlian mereka. Program pendidikan dan pelatihan kerja saran penting dalam pengembangan sumberdaya tenaga kerja yang di harapkan nantinya menjadi tenaga kerja yang siap pakai dalam artian bisa langsung terjun kelapangan kerja. Karena mengingat sebagian besar angkatan kerja di Indonesia masih bekerja pada sektor informal dengan produktivitas yang sangat rendah.

Menurut UU Ketenagakerjaan No. 13 Tahun 2003 di jelaskan bahwa Pelatihan kerja diselenggarakan dan di arahkan untuk membekali, meningkatkan, dan mengembangkan kompetensi kerja guna meningkatkan kemampuan, produktivitas, dan kesejahteraan. Pelatihan kerja dilaksanakan dengan memperhatikan kebutuhan pasar kerja dan dunia usaha, baik di dalam maupun di luar hubungan kerja.

Unit Pelaksana Teknis Daerah Balai Latihan Kerja ( UPTD BLK ) dibentuk berdasarkan Keputusan Bupati Nomor 17 Tahun 2018, tanggal 29 januari 2018 yang sebelumnya merupakan UPTD Loka Latihan Kerja Usaha Kecil Menengah ( UPTD LLK UKM ) berdasarkan Peraturan Daerah ( Perda ) Kabupaten Subang no. 14 tahun 2001 tentang Organisasi Unit Pelaksana Teknis Dinas Kabupaten Subang. Seiring dengan pelaksana Undang-undang Otonomi Daerah, mensyaratkan perubahan paradigma kepemerintahan yang ditandai dengan perubahan orientasi dari pola sentralistik menjadi desentralistik, dimana kedudukan lembaga latihan kerja yang semula berada dibawah tanggung jawab Departemen Tenaga Kerja Pusat beralih menjadi tanggung jawab Pemerintah Daerah, dalam hal ini Pemerintah Daerah Kabupaten Subang ( Perda No. 14 tahun 2001 ) tentang pembentukan Unit Pelaksana 
Teknis Dinas ( UPTD ) Latihan Kerja Unit Kegiatan Masyarakat (LK-UKM) dan Keputusan Bupati Subang Nomor 51 tentang Tugas Pokok dan Fungsi UPTD-LKUKM Subang, kemudian ditetapkan kembali dengan Keputusan Bupati Nomor : 14G/32 Tahun 2008 tentang Tugas Pokok dan Fungsi UPTD LLK UKM Dinas Tenaga Kerja dan Transmigrasi Kabupaten Subang, dan mengalami perubahan berdasarkan Peraturan Bupati Subang No. 17 Tahun 2018 Tanggal 29 Januari 2018 menjadi UPTD Balai Latihan Kerja Kabupaten Suban.

Salah satu strategi yang di tempuh untuk menghasilkan SDM yang komponen guna memenuhi kebutuhan dunia kerja ialah dengan menerapkan Pelatihan Berbasis Kompetensi (PBK) ini bisa menjadi media dalam rangka meningkatkan kualitas karakter maupun menambah kompetensi sesuai dengan kejuruan yang diminati. PBK merupakan suatu pendekatan pelatihan yang lebih spesifik dan terukur, yang lebih memberikan banyak praktik yakni $70 \%$ dan sisanya $30 \%$ teori agar peserta pelatihan akan menjadi terampil dan mahir menguasai bidang yang dipilihnya. Dilaksanakanya Pelatihan Berbasis Kompetensi ini untuk meningkatkan keterampilan, pengetahuan dan sikap kerja dari peserta yang berlatih sehingga terciptanya Sumber Daya Manusia dalam hal ini calon tenaga kerja yang berdaya saing sehingga siap masuk pasar kerja maupun untuk usaha mandiri. Adapun yang menjadi latar belakang diadakannya program pelatihan berbasis kompetensi di balai latihan kerja adalah pentingnya peningkatan kualitas sumber daya manusia agar memiliki daya saing dan memiliki standar global. Berbeda dengan pelatihan konvensional, PBK memerlukan standar kompetensi, sumber daya pelatihan dan metode pelatihan yang memenuhi persyaratan tertentu. Sebagai acuan pelaksanaan PBK telah diterbitkan Peraturan Mentri Tenaga Kerja dan Transmigrasi Nomor 8 tahun 2014 tentang Pedoman Penyelenggaraan Pelatihan Berbasis Kompetensi.

Di dalam UPTD BLK Pelatihan Berbasis Kompetensi (PBK) Kabupaten Subang terdapat pengertian bahwa programnya untuk membentuk calon tenaga kerja produktivitas sedangkan pelatihannya berupa kejuruan yang ada di berbagai macam jenis pelatihan yang di berikan antara lain yaitu Garment Apparel, TIK, Teknik Listrik, Teknik Pendingin, Teknik Las, Teknik Elektronika, Processing, Teknik Otomotif, Teknik Manukfakturyang berupa kompetensi. Pelatihan dilaksanakan selama 30 hari kerja pada hari senin sampai sabtu sehingga untuk estimasi waktu persatu angkatan pelatihan yakni kurang lebih satu setengah bulan. Program latihan kerja perlu diprioritaskan baik dalam rangka menghadapi era globalisasi dan persaingan dunia, maupun untuk mengatasi dampak krisis ekonomi mengurangi pengangguran. Dalam melaksanakan pelatihan kerja itu sendiri hendaknya di arahkan kesektor-sektor lapangan kerja yang banyak menyerap tenaga kerja sehingga pelatihan kejuruan yang diikuti akan membantu menjamin angkatan kerja dapat bekerja. Namun pada tahun 2018 calon tenaga kerja yang mengikuti Pelatihan belum sesuai dengan kebutuhan yang di minta oleh perusahaan-perusahaan atau lapangan kerja yang di butuhkan, kebutuhan akan tenaga ahli yang professional serta kebutuhan akan teknologiteknologi yang dapat mendukung suatu proses kerja, membuat perusahaan-perusahaan 
swasta, baik itu swasta asing maupun swasta nasional memerlukan tenaga kerja yang terampil dan ahli

Berdasarkan perkemabangannya yang masuk kedalam industri dan usaha sendiri baru 210 dari 656 peserta pelatihan sehingga Pelaksanaan Pelatihan kerjanya berjalan belum efektif di bawah 50\% dari target yang di inginkan $75 \%$ lulusanya dapat bekerja dengan baik, akan tetapi jika dilihat dari tahun 2018 banyaknya peserta pelatihan sebanyak 414 orang, baru 97 orang yang termonitor dan bekerja. Sehingga pada tahun 2018 ada sedikit peningkatan dari tahun sebelumnya walaupun masih belum mencapai target yang di inginkan. Pada tahun 2018 terdapat 607 perusahaan di Kabupaten Subang yang mendaftar ke DISNAKERTRANS untuk mendapatkan tenaga kerja yang di inginkan dan sesuai dengan kebutuhan perusahaan, namun dari banyaknya perusahaan tersebut di tahun 2018 hanya ada 345 perusahaan yang menyerap tenaga kerja diantaranya di bidang Garment, TIK, Teknik Listrik, Teknik Pendingin, Teknik Las, Teknik Elektronika, Prossesing, Teknik Otomotif, dan Teknik Munafaktur. Dari data tersebut terlihat, bahwa Perusahaan yang mendaftar lebih banyak membutuhkan tenaga kerja lulusan TIK (teknik informasi dan komunikasi) yaitu sebanyak 134 perusahaan, Ini dilihat dari data keseluruhan Perusahaan dan tenaga kerja di Kabupaten Subang tahun 2018. Maka jika di lihat dari data peserta pelatihan tahun 2018 lebih banyak peminat yang masuk kejuruan Garment dibandingkan dengan TIK.

Masalah sarana dan prasarana pelatihan juga masih belum memadai dari segi ruangan, peralatan atau mesin yang dibutuhkan, sebagian mesin yang ada di BLK sudah terbilang jadul atau kurang upgrade, seharusnya peralatan yang ada di BLK sudah setingkat seperti yang ada si pusat. BLK juga mengadakan seleksi untuk peserta yang peminatnya banyak dikarenakan keterbatasan ruangan dan peralatan, dikarenakan kapasitas dalam satu ruangan hanya 16 peserta, maka yang tidak lolos bisa masuk ke bulan selanjutnya atau bisa mengikuti pelatihan tahun depan. Seharusnya satu mesin satu orang dalam kenyataannya masih belum memadai seperti di bidang kejuruan otomotif hanya terdapat 7 mesin sedangkan kapasitas ruangan digunakan untuk 16 orang sehingga belum memenuhi satandar pelatihan yang di butuhkan para peserta. Kemudian dari segi instruktur pelatihan masih kurang, untuk pengadaan instruktur dari PNS/ASN sendiri masih dalam tahap rencana. Sehingga Program Pelatihan di UPTD BLK Kabupaten Subang ini perlu di kaji secara mendalam untuk mengetahui seberapa efektif kah pelaksanaan pelatihan dalam mencapai sasaran yang diharapkan sebelumnya.

Berdasarkan hasil pengamatan yang penulis lakukan pada UPTD Balai Latihan Kerja di Kabupaten Subang Nampaknya belum Efektif. Hal ini di lihat dari beberapa indikator sebagai berikut : 1) Pada tahun 2018, dari jumlah 656 peserta yang mengikuti Pelatihan Berbasis Kompetensi, Baru 210 orang yang termonitor dan bekerja sehingga Pelaksanaan Pelatihan kerjanya berjalan belum efektif yang di lihat dari hasil penelitian di bawah 50\% lulusanya dapat bekerja dengan baik; 2) Keterbatasan sarana dan prasarana pelatihan yang seharusnya satu orang satu mesin dalam kenyataannya masih belum memadai seperti di bidang kejuruan otomotif hanya terdapat 7 mesin 
sedangkan kapasitas ruangan digunakan untuk 16 orang sehingga kurang memenuhi standar pelatihan yang di butuhkan para peserta; dan 3) Sumber daya dari tenaga instruktur masih kurang memadai dari segi kuantitas.

\section{Kerangka Teori}

\section{a. Konsep Efektivitas dan Kinerja Program}

Efektivitas berasal dari kata efektif yang mengandung pengertian dicapainya keberhasilan dalam mencapai tujuan yang telah ditetapkan. Efektivitas selalu terkait dengan hubungan antara hasil yang di harapkan dengan hasil yang telah dicapai. Efektivitas dapat dilihat dari sudut pandang (view point) dan dapat dinilai dengan berbagai cara dan mempunyai kaitan yang erat dengan efesiensi. Seperti yang dikemukakan oleh Etzioni dalam bukunya Organisasi-organisasi Modern yang mendefinisikan efektivitas, sebagai berikut: "sebagai tingkat keberhasilan organisasi dalam usaha untuk mencapai tujuan dan sasaran" Etzioni, (1985:54-55).Bedasarkan pendapat di atas, bahwa apabila pencapaian tujuantujuan organisasi semakin besar, maka semakin besar pula efektifitasnya. Dari pengertian tersebut dapat disimpulkan adanya pencapaian tujuan yang besar daripada organisasi maka makin besar pula hasil yang akan dicapai dari tujuantujuan tersebut. Efektivitas merupakan suatu konsep yang sangat penting karena mampu memberikan gambaran mengenai keberhasilan suatu organisasi dalam mencapai sasaran atau tujuan yang diharapkan.

Menurut pendapat Mahmudi (2015:86) mendefinisikan efektivitas, sebagai berikut: "efektivitas merupakan hubungan antara output dengan tujuan, semakin besar kontribusi (sumbangan) output terhadap pencapaian tujuan, maka semakin efektif organisasi, program atau kegiatan". Efektivitas berfokus pada outcome (hasil). Suatu organisasi, program, atau kegiatan dinilai efektif apabila output yang dihasilkan dapat memenuhi tujuan yang diharapkan atau dikatakan spending wisely. Untuk lebih jelasnya dapat dilihat pada Gambar 1 mengenai hubungan arti efektivitas dibawah ini:

Gambar 2.1

Hubungan Efektivitas

Efektivitas $=\frac{\text { Outcome }}{\text { Output }}$

Sumber: Mahmudi, 2015:86.

Sehubungan dengan hal tersebut di atas, maka efektivitas adalah menggambarkan seluruh siklus input, proses dan output yang mengacu pada hasil daripada suatu organisasi, program atau kegiatan yang menyatakan sejauh mana tujuan (kualitas, kuantitas, dan waktu) telah dicapai, serta ukuran berhasil 
tidaknya suatu organisasi mencapai tujuannya dan mencapai target-targetnya. Hal ini berarti, bahwa pengertian efektivitas yang dipentingkan adalah semata-mata hasil atau tujuan yang dikehendaki. Dari beberapa pendapat di atas, bahwa konsep efektivitas merupakan suatu konsep untuk mendefinisikan efektivitas berbeda-beda sesuai dengan dasar ilmu yang dimiliki walaupun tujuan akhirnya adalah pencapaian tujuan. Pada umumnya efektivitas sering dihubungkan dengan efesiensi walaupun artinya berbeda, sesuatu yang dilakukan secara efesien belum tentu efektif.

Sedangkan menurut Siagian (2008:20-21) Efektivitas adalah pemanfaatan sumberdaya, dana, sarana dan prasarana dalam jumlah tertentu yang secara sadar ditetapkan sebelumnya untuk menghasilkan sejumlah barang atau jasa dengan mutu tepat pada waktunya. Menurut pendapat Markus Zahnd dalam bukunya "perancangan kota secara terpadu" mendefinisikan efektivitas dan efesiensi, sebagai berikut: "Efektivitas yaitu berfokus pada akibatnya, pengaruhnya atau efeknya, sedangkan efesiensi berarti tepat atau sesuai untuk mengerjakan sesuatu dengan tidak membuang-buang waktu, tenaga dan biaya" (Zahnd, 2006:200). Menurut Agung Kurniawan dalam bukunya Transformasi Pelayanan Publik mendefinisikan efektivitas, "Efektivitas adalah kemampuan melaksanakan tugas, fungsi (operasi kegiatan program atau misi) daripada suatu organisasi atau sejenisnya yang tidak adanya tekanan atau ketegangan diantara pelaksanaannya" (Kurniawan, 2005:109). Dari pe njelasan di atas, bahwa efektivitas lebih memfokuskan pada akibat atau pengaruh sedangkan efesiensi menekankan pada ketepatan mengenai sumber daya, yaitu mencakup anggaran, waktu, tenaga, alat dan cara supaya dalam pelaksanaanya tepat waktu. Untuk itu faktor keefektifannya banyak menentukan kepada kemampuan aparatur dan organisasi dalam melaksanakan tugas dan kewenangan. Tingkat pencapaian tujuan aparatur dalam suatu organisasi dikatakan efektif apabila pencapaian itu sesuai dengan tujuan organisasi dan memberikan hasil yang maksimal. Hal tersebut juga sejalan dengan pendapat yang dikemukakan Sedarmayanti dalam bukunya yang berjudul Sumber Daya Manusia dan Produktivitas Kerja mengenai pengertian efektivitas yaitu : "Efektivitas merupakan suatu ukuran yang memberikan gambaran seberapa jauh target dapat tercapai. Pengertian efektivitias ini lebih berorientasi kepada keluaran sedangkan masalah penggunaan masukan kurang menjadi perhatian utama. Apabila efesiensi dikaitkan dengan efektivitas maka walaupun terjadi peningkatan efektivitas belum efesiensi meningkat" (Sedarmayanti, 2001: 59). Efektivitas merupakan unsur pokok untuk mencapai tujuan atau sasaran yang telah ditentukan dalam setiap organisasi. Efektivitas disebut juga efektif, apabila tercapainya tujuan atau sasaran yang telah ditemukan sebelumnya. Hal ini sesuai dengan pendapat $\mathrm{H}$. Emerson yang dikutif Soewarno Handayaningrat dalam buku "Pengantar Studi Ilmu Administrasi dan Manajemen" mengatakan bahwa efektivitas adalah pengukuran dalam arti tercapainya tujuan yang telah ditentukan sebelumnya (Handayaningrat:1994:16). Secara umum program diartikan sebagai "rencana" menurut Suharsimi Arikunto dan Cepi Sufrudin 
Program didefinisikan sebagai suatu unit atau kesatuan kegiatan yang merupakan realisasi atau implementasi dari suatu kebijakan, berlangsung dalam proses yang berkesinambungan, dan terjadi dalam suatu organisasi yang melibatkan sekelompok orang.

Sebagai pemaparan tersebut dapat disimpulkan bahwa efektivitas program adalah merupakan keberhasilan organisasi dalam menjalankan program atau kebijakannya melalui berbagai sarana dan cara serta upaya memanfaatkan segala sumber daya dalam mencapai tujuan yang telah ditetapkan. Menurut Julia (2010: 26) Pengertian Efektivitas Program yaitu dapat dirumuskan sebagai tingkat perwujudan sasaran yang menunjukkan sejauh mana sasaran program yang telah ditetapkan.

Hubungan administrasi dengan efektivitas ialah sangat erat kaitannya karena efektivitas termasuk salah satu aspek ilmu administrasi. Efektivitas merupakan hal penting dalam pelaksanaan administrasi. Peran efektivitas itu sendiri berbicara tentang bagaimana suatu hasil dari tujuan yang telah ditentukan dalam pelaksanaan administrasi. Baik pelaksanaan administrasi maupun pelaksanaan yang lainnya pasti berorientasi kepada efektivitas atau hasil. Oleh karenanya efektivitas dan administrasi erat kaitannya. Pada umumnya, kinerja diberikan batasan sebagai kesuksesan seseorang di dalam melakukan suatu pekerjaan. Kinerja merupakan salah satu alat ukur bagi pencapaian tujuan organisasi. Hasibuan (2002:45) juga mengartikan kinerja (prestasi kerja) sebagai hasil kerja secara kualitas dan kuantitas yang di capai oleh seorang pegawai dalam melaksanakan tugasnya sesuai dengan tanggung jawab yang diberikan kepadanya. Menurut Mahsun $(2006,25)$ kinerja adalah gambaran mengenai tingkat pencapaian pelaksanaan suatu kegiatan / program/kebijakan dalam mewujudkan sasaran, tujuan, misi, dan visi organisasi yang tertuang dalam strategic planning suatu organisasi. Sehingga Dalam pengertian kinerja program yaitu berkenaan dengan sampai beberapa jauh kegiatan-kegiatan dalam program yang telah dilaksanakan sehingga dapat mencapai tujuan dari program tersebut.

\section{b. Pendekatan Terhadap Efektivitas}

Pendekatan efektivitas dilakukan dengan acuan berbagai bagian yang berbeda dari lembaga, dimana lembaga mendapatkan input atau masukan berupa berbagai macam sumber dari lingkungannya. Kegiatan dan proses internal yang terjadi dalam lembaga mengubah input menjadi output atau program yang kemudian di lemparkan kembali pada lingkungannya (Price, 1972:15).

1) Pendekatan sasaran (Goal Approach)

2) Pendekatan ini mencoba mengukur sejauh mana suatu lembaga berhasil merealisasikan sasaran yang hendak dicapai. Pendekatan sasaran dalam pengukuran efektivitas dimulai dengan identifikasi sasaran organisasi dan mengukur tingkatan keberhasilan organisasi dalam mencapai sasaran tersebut. Sasaran yang perlu di perhatikan dalam pengukuran efektivitas dengan pendekatan ini adalah sasaran yang realistic untuk 
memberikan hasil maksimal berdasarkan sasaran resmi " Official Goal " dengan memperhatikan permasalahan yang ditimbulkannya. Dengan demikian, pendekatan ini mencoba mengukur sejauh mana organisasi atau lembaga berhasil merealisasikan sasaran yang hendak dicapai.

3) Pendekatan Sumber ( System Resource Approach)

4) Pendekatan sumber mengukur efektivitas melalui keberhasilan suatu lembaga dalam mendapatkan berbagai macam sumber yang dibutuhkannya. Suatu lembaga harus dapat memperoleh berbagai macam sumber dan juga memelihara keadaan dan sistem agar dapat menjadi efektif.

5) Pendekatan Sumber ( System Resource Approach )

6) Pendekatan ini didasarkan pada teori mengenai keterbukaan sistem suatu lembaga terhadap lingkungannya, karena lembaga mempunyai hubungan yang merata dalam lingkungannya dimana dari lingkungan diperoleh sumber-sumber yang terdapat pada lingkungan sering kali bersifat langka dan bernilai tinggi.

7) Pendekatan Proses (Internal Proses Approach)

8) Pendekatan proses menganggap sebagai efesiensi dari suatu lembaga internal. Pada lembaga yang efektif, proses internal berjalan dengan lancer dimana kegiatan bagian-bagian yang ada berjalan secara terkoordinasi. Pendekatan ini tidak memperhatikan lingkungan melainkan memusatkan perhatian terhadap kegiatan yang dilakukan terhadap sumber-sumber yang dimiliki lembaga, yang menggambakan tingkat efesiensi serta kesehatan lembaga.

\section{c. Pengukuran Efektivitas dan Kinerja program}

Menurut Campbell (2004:121) Pengukuran Efektivitas secaraa umum dan yang paling menonjol adalah :

1) Keberhasilan program

2) Program adalah sekumpulan aktiviti yang saling berkaitan dan bantu membantu diantara satu dengan lain kepada pencapaian suatu tujuan program itu. Sebuah organisasi itu mungkin mengandung satu atau lebih program dan tujuan tiap-tiap program itu adalah tidak serupa tetapi ia saling menyumbang kepada satu tujuan sebuah organisasi itu.

3) Maksudnya adalah program yang diluncurkan oleh pemerintah benarbenar akan berhasil dalam kurun waktu yang dapat ditentukan sehingga masyarakat dapat menikmati program tersebut.

4) Keberhasilan sasaran

5) Sasaran/goal adalah suatu keadaan atau kondisi yang ingin dicapai oleh suatu organisasi, bisa tujuan jangka pendek atau jangka panjang, bisa mencakup organisasi keseluruhan dan bisa mencakup bagian organisasi tertentu, sebagai alat ukur efesiensi dan efektivitas organisasi. Tentunya program pemerintah mempunyai sasaran yang jelas dan terukur, baik 
sasaran siapa yang akan menikmati program, dan sasaran tersebut dapat melanjutkan secara mandiri program yang sudah bergulir.

6) Kepuasan terhadap program

7) Program yang dibuat oleh pemerintah benar-benar harus memuaskan seluruh komponen masyarakat tanpa terkecuali. Hal ini dilakukan agar masyarakat dapat menikmati keberhasilan program yang sedang bergulir.

8) Tingkat input dan output

9) Input merupakan masukan kepada program-program yang sedang berjalam, baik berupa sumber daya manusia, sumber daya fisik dan sumber daya keuangan. Sumber-sumber tersebut dapat dikelola dengan baik agar output yang dihasilkan agar maksimal.

10) Pencapaian tujuan menyeluruh

11) Keberhasilan dari suatu program merupakan tujuan utama dari pencapaian rencana. Artinya tujuan yang diharapkan harus menjadi tujuan umum dan mencakup kepentingan masyarakat tanpa terkecuali. Sehingga efektivitas program dapat dijalankan dengan kemampuan operasional dalam melaksanakan program-program kerja yang sesuai dengan tujuan yang telah ditetapkan sebelumnya, secara komprehensif, efektivitas dapat diartikan sebagai tingkat kemampuam suatu lembaga atau organisasi untuk dapat melaksanakam semua tugas-tugas pokoknya atau untuk mencapai sasaran yang telah ditentukan sebelumnya (Campbell, 1989:47). Menurut pendapat Gibson Ivancevich Donnelly (1990:28) menyebutkan bahwa untuk merumuskan dan mengukur keefektifan adalah teknik evaluasi tertua dan digunakan secara luas. Menurut pendekatan tujuan ini sebuah organisasi didirikan untuk mencapai tujuan. Seorang praktisi dan penulis organisasi Chester menyatakan "apa yang kita maksudkan dengan keefektifan adalah pencapaian tujuan yang ditetapkan dengan usaha kerja sama" pendapat yang mempunyai pertimbangan luas, menyatakan bahwa organisasi, sebagaimana halnya individu dan kelompok, harus dievaluasi menurut ukuran pencapaian tujuan. Ada lima kategori umum kriteria keefektifan mulai dimensi waktu jangka pendek menurut Gibson (1990:33-35) sebagai berikut: Produksi adalah mengacu pada ukuran keluaran utama organisasi; Efesiensi adalah mengacu pada ukuran penggunaan sumberdaya yang langka oleh organisasi; Kepuasan adalah menjadi ukuran keberhasilan organisasi memenuhi kebutuhan karyawan dan anggotanya; Keadaptasian adalah suatu ukuran ketanggapan organisasi terhadap tuntutan perubahan; dan Pengembangan adalah mengukur tanggung jawab organisasi dalam memperbesar kapasitas dan potensinya untuk berkembang. Menurut Jerry Harbour (2009:35) dalam buku The basics of Performance Measurement, merekomendasikan Pengukuran Kinerja dengan beberapa aspek, yaitu: Produktivitas : 
kemampuan dalam menghasilkan produk barang dan jasa; Kualitas : pemproduksian barang dan jasa yang dihasilkan memenuhi standar kualitas; Ketepatan waktu (timeliness): waktu yang diperlukan dalam menghasilkan produk barang dan jasa tersebut; Putaran waktu: waktu yang dibutuhkan dalam setiap proses perubahan barang dan jasa tersebut kemudian sampai kepada pengguna konsumen/konsumen; Penggunaan sumber daya; sumberdaya yang diperlukan dalam menghasilkan produk barang dan jasa tersebut; dan Biaya : biaya yang diperlukan. Ukuran ini merupakan suatu ukuran yang menitiberatkan pada hitungan per unit dasar, penggunaan satuan biaya perhari pelatihan dalam beberapa kasus walaupun organisasi memiliki banyak informasi secara total biaya namun mereka sebenarnya mereka punya keterbatasan biaya perunit.

\section{d Masalah dalam Pengukuran Efektivitas}

Efektivitas selalu diukur berdasarkan prestasi, produktivitas. Seperti ada beberapa rancangan tentang memandang konsep ini dalam kerangka kerja dimensi satu, yang memusatkan perhatian hanya dengan menggunakan sasaran yang sebenarnya dan memberikan hasil daripada pengukuran efektivitas berdasarkam sasaran resmi dengn memperhatikan masalah yang ditimbulkan oleh beberapa hal berikut:

1) Adanya macam-macam output

2) Adanya bermacam-macam output yang dihasilkan menyebabkan pengukuran efektivitas dengan pendekatan sasaran menjadi sulit untuk dilakukan. Pengukuran juga semakin sulit jika ada sasaran yang saling bertentangan dengan sasaran lainnya.

3) Efektivitas tidak akan dapat diukur hanya dengan mengunakan suatu indikator atau efektivitas yang tinggi pada suatu sasaran yang seringkali disertai dengan efektivitas yang rendah pada sasaran lainnya. Selain itu, masalah itu juga muncul karena adanya bagian-bagian dalam suatu lembaga yang mempunyai sasaran yang berbeda-beda secara keseluruhan. sehingga pengukuran efektivitas seringkali terpaksa dilakukan dengan memperhatikan bermacam-macam secara simultan. Dengan demikian, yang diperoleh dari pengukuran efektivitas adalah profil atau bentuk dari efek yang menunjukan ukuran efektivitas pada setiap sasaran yang dimilikinya.

4) Subyektifitas dalam adanya penelitian

5) Pengukuran efektivitas dengan menggunakan pendekatan sasaran seringkali mengalami hambatan, karena sulitnya mengidentifikasi sasaran yang sebenarnya dan juga karena kesulitan dan pengukuran keberhasilan dalam mencapai sasaran. Untuk itu ada baiknya bila meninjau pendapat G.W England, bahwa perlu masuk kedalam suatu lembaga untuk mempelajari sasaran yang sebenarnya karena informasi yang diperoleh 
hanya dari dalam suatu lembaga untuk melihat program yang berorientasi keluar atau masyarakat, seringkali dipengaruhi oleh subyektifitas.

6) Untuk sasaran yang harus dideskripsikan secara kuantitatif, informasi yang diperoleh akan sangat tergantung pada subyektifitas dalam suatu lembaga mengenai sasarannya. Hal ini didukung oleh pendapat Richard M Steers yaitu bahwa lingkungan dan keseluruhan elemen-elemen kontekstual pengaruh terhadap informasi lembaga dan menentukan tercapai tidaknya sasaran yang hendak dicapai (Steers, 1985:558)

7) Adapun pengertian Efektivitas program yaitu dapat dirumuskan sebagai tingkat perwujudan sasaran yang menunjukkan sejauh mana sasaran program yang telah ditetapkan Julia (2010: 26). Berdasarkan beberapa pengertian efektivitas di atas, dapat dipahami bahwa efektivitas merupakan sebuah patokan untuk membandingkan antara proses yang dilakukan dengan tujuan dan sasaran yang dicapai. Suatu program dikatakan efektif apabila usaha atau tindakan yang dilakukan sesuai dengan hasil yang diharapkan. Efektivitas digunakan sebagai tolok ukur untuk membandingkan antara rencana dan proses yang dilakukan dengan hasil yang dicapai.

\section{Metode Penelitian}

Metode penelitian yang dipergunakan dalam penelitian ini yaitu penelitian kualitatif. Menurut Moleong (2007:6), penelitian kualitatif adalah penelitian yang bermaksud untuk memahami fenomena tentang apa yang dialami oleh subjek penelitian misalnya perilaku, persepsi, motivasi, tindakan, dll secara holistic, dan dengan cara deskripsi dalam bentuk kata-kata dan bahasa, pada suatu konteks khusus yang alamiah dan dengan memanfaatkan berbagai metode alamiah. Menurut Sugiyono (2009:15), metode penelitian kualitatif adalah metode penelitian yang berlandaskan pada filsafat post positivisme, digunakan untuk meneliti pada kondisi obyek yang alamiah, (sebagai lawannya eksperimen) dimana peneliti adalah sebagai instrumen kunci, pengambilan sampel sumber data dilakukan secara purposive dan snowball, teknik pengumpulan dengan trianggulasi (gabungan), analisis data bersifat induktif atau kualitatif, dan hasil penelitian kualitatif lebih menekankan makna dari pada generalisasi.

\section{Hasil dan Pembahasan}

Unit Pelaksana Teknis Daerah Balai Latihan Kerja ( UPTD BLK ) beralamat di Jl. Mayjend Sutoyo No. 48 Kabupaten Subang, dibentuk berdasarkan Keputusan Bupati Nomor 17 Tahun 2018, tanggal 29 januari 2018 yang sebelumnya merupakan UPTD Loka Latihan Kerja Usaha Kecil Menengah ( UPTD LLK UKM) berdasarkan Peraturan 
Daerah ( Perda ) Kabupaten Subang no. 14 tahun 2001 tentang Organisasi Unit Pelaksana Teknis Dinas Kabupaten Subang.

Perkembangan UPTD LK-UKM Kabupaten Subang sejak berdirinya tahun 1984 sanpai tahun 2000 di tandai dengan beberapa tahap perkembangan. Pada periode tahun 1984-1992 UPTD LK - UKM Kabupaten Subang merupakan Bengel Pengembangan Teknologi Tepat Guna ( BPTTG) yang merupakan organisasi dibawah Sub Direktorat Pembinaan Teknologi dan Pengembangan Sistem Pada Karya ( Dirjen Bina Penta ) Departemen tenaga Kerja. Berfungsi sebagai bengkel menguji coba teknologi Padat Karya dan teknologi pedesaan baik teknologi yang berasal dari luar negeri maupun dalam negeri yang merupakan sistem teknologi Padat Karya alam alih teknologi kepada para petugas lapangan teknologi sistem Padat Karya ( PL - TSPK ). Masyarakat calon pengguna dan dinas / instansi dan lembaga lain yang membutuhkan sistem Teknologi Padat Karya, yang mencakup wilayah seluruh Indonesia. Seperti yang telah dikemukakan sebelumnya, bahwa untuk mengukur efektivitas program pelatihan berbasis kompetensi maka untuk bisa mengukur efektif atau tidaknya di ukur menggunakan pengukuran kinerja menggunakan teori yang dikemukakan oleh Jerry Harbour (2009:35) bahwa faktor penentu keberhasilan program pelatihan mencakup, Produktivitas, Kualitas, Ketepatan Waktu, Putaran Waktu, Sumber Daya, dan Biaya. Untuk dapat mengetahuinya akan penulis bahas sebagai berikut: berikut :

Dalam bahasan berikut penulis akan membahas faktor produktivitas sebagai

Menurut Jerry Harbour Produktivitas yaitu Mencerminkan Kemampuan dalam menghasilkan barang dan jasa Berkaitan dengan produksi atau kuantitas latihan. Berikut ini wawancara dengan Kepala UPTD BLK Kabupaten Subang : " Pelatihan Berbasis Kompetensi (PBK) adalah pelatihan kerja yang menitikberatkan pada penguasaan kemampuan kerja yang mencakup peng pertama akan dikaji tentang faktor Produktivitas; pengetahuan, keterampilan dan sikap sesuai dengan standar yang di tetapkan dan persyaratan di tempat kerja. dalam setiap tahun nya UPTD BLK Kabupaten Subang melatih calon tenaga kerja yang ada di Kabupaten Subang Tahun 2018 sebanyak 1.700 orang dari kurang lebih 2000 orang yang mendaftar atau berminat mengikuti pelatihan kerja, yang mengikuti pelaksanaan secara institusional sebanyak 656 orang dari berbagai kejuruan yang ada yaitu kejuruan Teknik manufaktur, Teknik elektronika, Otomotif, TIK, Teknik Listrik, Teknik Pendingin, Garment Apparel, Teknik Las, dan Prossesing, hal ini disesuaikan dengan kemampuan anggaran yang kami miliki serta sarana dan prasarana pelatihan yang ada juga sumber daya yang kami miliki dalam hal tenaga instruktur". Berdasarkan kutipan wawancara dengan kepala UPTD BLK Kabupaten Subang, penulis menarik kesimpulan bahwa Pelatihan Berbasis kompetensi (PBK) adalah pelatihan yang dapat menguasai kemampuan kerja dalam pengetahuan, keterampilan, dan sikap. Pada tahun 2018 UPTD BLK Kabupaten Subang yang mengikuti pelaksanaan pelatihan secara institusional hanya mampu melatih peserta pelatihan sebanyak 656 orang dari 1.700 orang yang diterima di BLK Subang untuk mendaftar atau berminat mengikuti pelatihan, disesuaikan dengan kemampuan 
anggaran, sarana dan prasarana serta instruktur yang ada saat ini. Kutipan wawancara dengan Ka Subag TU UPTD BLK Kabupaten Subang: " yang mendaftar pelatihan pada tahun 2018 ada sekitar 2000 orang peserta pelatihan yang berminat mengikuti pelatihan di UPTD BLK Kabupaten Subang, namun yang kami terima hanya 1700 orang peserta untuk yang dilaksanakan secara institusional hanya 656 orang yang terbagi menjadi beberapa kejuruan, ada beberapa kejuruan yang melaksanakan pelatihan lebih dari satu paket dikarnakan jumlahnya paling banyak, contohnya kejuruan menjahit karna pada saat itu kejuruan tersebut sangat dibutuhkan oleh perusahaan dilihat dari data bahwa dari tahun 2014-2018 didominasi oleh kejuruan Garment, di tahun 2018 pelaksanaan secara institusional siswa yang lulus 220 orang dan sebagian peserta telah ditempatkan di perusahaan dan juga berwirausaha". Observasi yang penulis lakukan langsung di UPTD BLK Kabupaten Subang penulis membandingkan dan menanyakan pelaksanaan tahun lalu dengan pelaksanaan yang sekarang sedang dilaksanakan pelatihan secara institusional dari berbagai kejuruan yang ada, ternyata tidak semua peserta pelatihan yang mendaftar mengikuti pelatihan dapat diterima menjadi peserta pelatihan. Berdasarkan hasil observasi yang penulis lakukan ada beberapa hal yang mengakibatkan tidak seluruhnya peserta pelatihan yang mendaftar dapat mengikuti pelatihan diantaranya kurangnya sarana dan prasarana serta sumber daya yang ada. Pada kejuruan Garment hanya terdapat satu instruktur PNS dan empat non PNS padahal peserta yang berminat mengikuti pelatihan sangat banyak sehingga sangat mempengaruhi kualitas yang akan dihasilkan dan keterbatasan anggaran yang tersedia

Dari hasil wawancara dan observasi yang penulis lakukan terhadap kemampuan dalam menghasilkan barang dan jasa seperti yang dituntut oleh lingkungan, kemampuan UPTD BLK Kabupaten Subang dalam melaksanakan kegiatan pelatihan tahun 2018 penulis mengambil kesimpulan bahwa tidak semuanya peserta pelatihan yang mendaftar dapat mengikuti pelatihan kerja di UPTD BLK Kabupaten Subang dikarenakan kurangnya sarana dan prasarana pelatihan dan keterbatasan anggaran biaya pelatihan serta kurangnya sumberdaya manusia dalam hal ini Tenaga Insruktur yang dapat mengakibatkan turunnya kuantitas dan kualitas calon tenaga kerja yang mengikuti pelatihan di UPTD BLK Kabupaten Subang. Apabila permasalahan tersebut dikaitkan dengan teori yang dikemukakan oleh Jerry Harbour dalam Dasar-dasar Pengukuran Kinerja (2009:35-36), bahwa Ini biasanya dinyatakan sebagai hubungan antara input dan output fisik dari proses yang ditentukan, yaitu hubungan antara jumlah output versus sumber daya dikonsumsi dalam memproduksi output tersebut. Yang artinya jika ingin mendapatkan hasil yang baik proses pelaksanaan pelatihan yang diberikan harus sesuai dengan kurikulum yang ada. Seperti sumberdaya instruktur yang ada di UPTD BLK Kabupaten Subang di tingkatkan dan di tambah lagi dan untuk mendukung keberhasilan yang di inginkan peralatan yang diberikan kepada peserta juga harus di tinggkatkan.

Hasil kajian terhadap faktor Kualitas dapat dijelaskan sebagai berikut :

Menurut Jerry Harbour Kualitas adalah pemproduksian barang dan jasa yang dihasilkan memenuhi standar kualitas. Kutipan wawancara dengan Ka. Subag BLK 
Kabupaten Subang :"sasaran kegiatan pelatihan yang dilaksanakan di UPTD BLK Kabupaten Subang adalah para pencari kerja yang ada di Kabupaten Subang dimana untuk pelatihan yang dilaksanakan secara institusional kita laksanakan berdasarkan hasil analisa kebutuhan pelatihan dimana tim kita sebelum melaksanakan pelatihan melakukan pendataan kepada perusahaan untuk mengetahui tenaga kerja yang dibutuhkan diperusahaan tersebut, kami juga selalu berusaha menempatkan para peserta yang telah mengikuti pelatihan baik itu keperusahaan ataupun berwiraswasta, yang telah mengikuti pelatihan akan dapat langsung ditempatkan di perusahaan yang ada di Kabupaten Subang dan sebagian kita tempatkan diluar Kabupaten Subang, dan Alhamdulillah dapat diterima oleh perusahaan walau tidak semuanya, adapun para peserta pelatihan kami arahkan untuk berwira usaha membuka usaha baru, kualitas yang di hasilkanpun yang dilaksanakan institusional hampir $50 \%$ peserta pelatihan dinyatakan kompeten". Berdasarkan wawancara diatas, penulis menarik kesimpulan bahwa kegiatan pelatihan yang dilaksnakan di UPTD BLK Kabupaten Subang telah memenuhi kebutuhan masyarakat terhadap pelatihan yang di inginkan serta telah disesuaikan dengan kebutuhan industri atau perusahaan, hal ini terlihat adanya kegiatan Traning Need Analysis atau Analisa Kebutuhan Pelatihan sebelum kegiatan pelatihan dilaksanakan dan dapat memenuhi kebutuhan masyarakat, dengan adanya penempatan calon tenaga kerja yang telah mengikuti pelatihan di beberapa perusahaan yang ada di kabupaten subang maupun di tempat lain juga membuka usaha baru sendiri, dan kualitas yang dihasilkan secara institusional hampir $50 \%$ peserta pelatihan dinyatakan kompeten.Berikut ini kutipan wawancara dengan petugas Teknis Operasional : " yang mengikuti pelatihan disini sangat banyak sehingga ada kejuruan yang di bagi menjadi beberapa tahap , bahkan ada kejuruan pesertanya harus di seleksi terlebih dahulu dikarekanan ruangan dan alat yang tidak memadai, dan dari segi Tenaga Instruktur nya contoh di kejuruan Garmen hanya ada satu instruktur PNS dan empat Non PNS sehingga sangat mempengruhi kualitas yang akan dihasilkan". Hasil wawancara dengan petugas Teknis Operasional yang penulis lakukan dapat ditarik kesimpulan bahwa banyaknya peserta pelatihan di UPTD BLK Kabupaten Subang yang mendaftar dan mengikuti pelatihan sehingga diadakan seleksi bagi beberapa kejuruan yang peminatnya banyak dan dibagi menjadi beberapa tahap dalam pelaksanaan pelatihannya karena keterbatasan ruangan dan alat yang digunakan oleh peserta, dan tenaga instruktur yang kurang memadai, sehingga sangat mempengaruhi kualitas lulusan yang dihasilkan. Dari hasil wawancara dan observasi yang penulis lakukan, penulis mempunyai kesimpulan bahwa pelatihan yang dilaksanakn dapat memenuhi harapan dan kebutuhan masyarakat terhadap pelatihan yang dilaksanakan. Dan penulis menyimpulkan bahwa kualitas yang dihasilkan dalam pelaksanaan pelatihan di UPTD BLK Kabupaten Subang menunjukan hasil hampir 50\% peserta pelatihan yang dilaksanakan secara institusional dinyatakan Kompeten. Apabila permasalahan tersebut dikaitkan dengan teori yang dikemukakan oleh Jerry Harbour dalam pengukuran kinerja (2009:35-36), bahwa Kualitas yang baik yaitu pemproduksian barang dan jasa yang dapat dihasilkan memenuhi standar kualitas. Dalam hal ini peserta pelatihan harus benar-benar mendapatkan pelayanan yang baik sesuai standar 
kualitas atau pelatihan yang dilaksanakan dapat memenuhi harapan dan kebutuhan masyarakat terhadap pelatihan yang dilaksanakan.

Kemudian hasil kajian terhadap faktor Ketepatan waktu dapat dikemukaakn sebagai berikut :

Menurut Jerry Harbour Ketepatan waktu (Timeliness) adalah waktu yang diperlukan dalam menghasilkan produk barang dan jasa tersebut. Berikut kutipan wawancara yang penulis lakukan berkaitan dengan ketepatan waktu : Kutipan hasil wawancara dengan Kasubag TU BLK Kabupaten Subang :" waktu yang di berikan kepada peserta pelatihan sudah sesuai dengan apa yang di tentukan, seperti hal nya waktu dalam pelaksanaan per satu angkatan dilaksanakan 30hari kerja pada hari senin sampe hari sabtu sekitar 8 jam perhari dari jam 8pagi sampe jam 4sore sehingga untuk estimasi waktu persatu angkatan yakni kurang lebih satu setengah bulan dengan lama latihan yang bervariasi ada yang 980jam, 640 jam, 480 jam dan 240 jam, dengan biaya dari pemerintah dan daerah kita gunakan seefesien mungkin, dan di akhir pelatihan para peserta diberikan sertifikat sesuai dengan kejuruan dan sub-kejuruan yang diikutinya". Berikut kutipan hasil wawancara dengan instruktur UPTD BLK Kabupaten Subang:" kami melatih peserta sesuai dengan kurikulum yang diberikan setiap peserta kami kasih buku panduan atau modul untuk menyampaikan teori dan praktek yang akan di berikan, karena waktu untuk peserta platihan yang ada di BLK ini 30\% teori dan $70 \%$ praktek sama hal seperti SMK namun bedanya disini lebih banyak waktu untuk membahas dan mempraktekan sesuai kejuruan yang di ambil dan lebih mendalami atau memahami jurusan yang di ambil dengan per hari 8jam dari hari senin sampai hari sabtu menurut saya sudah cukup tepat dalam hal waktu yang di berikan, namun kami masih kesulitan dalam menyesuaikan antara kurikulum dengan peralatan sebagai sarana pendukung, karena peralatan yang kami miliki saat ini masih kurang dan sudah tidak sesuai dengan kondisi, sehingga kami memanfaatkan sarana pelatihan yang ada dengan tidak mengurangi tujuan pelatihan yang telah di tetapkan". Kutipan hasil wawancara dengan peserta pelatihan :" dari segi waktu pelatihan disini menurut saya sudah cukup, kami mengikuti pelatihan disini selama kurang lebih satu setengah bulan dari hari senin sampai hari sabtu dimulai dari jam 8 sampe jam 4 sore belajar, tetapi dengan kondisi yang ada kami kesulitan untuk menggunakan alat karena peralatan yang ada masih kurang sebagai sarana pendukung, kadang kami harus bergantian menggunakan mesin, sehingga kita gunakan mesin seefesien mungkin agar tepat waktu". Bedasarkan hasil wawancara dengan kepala dan instruktur pelaksana UPTD BLK Kabupaten Subang, serta peserta pelatihan berkaitan dengan ketepatan waktu program pelatihan yang di laksanakan secara intitusional, bahwa peserta yang telah mengikuti pelatihan di UPTD BLK Kabupaten Subang sudah cukup tepatwaktu karena sudah sesuai dengan kurikulum yang diberikan kepada para peserta dengan estimasi waktu 8jam perhari dibandingkan dengan sekolahan SMK disini para peserta bisa lebih fokus dan mendalami kejuruan yang mereka ambil, namun sarana dan prasarana pelatihan sebagai sarana pendukung belum sepenuhnya menunjang kepada 
kegiatan pelatihan mengingat peralatan yang ada saat ini di beberapa kejuruan kondisinya sudah lama dan bahkan ada yang tidak bisa digunakan sama sekali.

Bedarkan hasil wawancara dan observasi yang penulis lakukan bahwa pelatihan di UPTD BLK Kabupaten Subang yang dilaksanakan secara intitusional berkaitan dengan Ketepatan waktu bahwa pelatihan yang dilaksanakan sesuai dengan kejuruan yang di ambil maka estimasi waktunya berbeda-beda namun tepat waktu walaupun penulis melihat sarana dan prasarana yang ada saat ini dibeberapa kejuruan kondisinya tidak sesuai sehingga pelatihan yang ada belum menunjang sepenuhnya terhadap kurikulum. Dan apabila di kaitkan dengan teori yang dikemukakan oleh Jerry Harbour dalam pengukuran kinerja (2009:35-36), bahwa ketepatan waktu yang diperlukan dalam menghasilkan produk barang dan jasa tersebut, jika melihat estimasi waktunya yang berbeda-beda namun tepat waktu sesuai kurikulum yang diberikan.

Hasil kajian terhadap faktor Putaran Waktu dapat dijelaskan sebagai berikut :

Menurut Jerry Harbour Putaran waktu adalah waktu yang di butuhkan dalam setiap proses perubahan barang dan jasa tersebut kemudian sampai kepada pengguna konsumen. Berikut ini kutipan hasil wawancara yang penulis lakukan dengan berbagai sumber : Kutipan wawancara dengan KasuBag TU BLK Kabupaten Subang :.... menyikapi kemajuan dunia industri saat ini dihubungkan dengan Siklus setiap proses peningkatan program pelatihan yang dilaksanakan pada setiap tahunnya kami terus melakukan penyesuaian dengan kemajuan dunia industri pada saat ini sehingga memang ada peningkatan, bisa dilihat dari segi program pelatihan meliputi kurikulum, sumberdaya manusia, penyelenggara pelatihan termasuk instruktur dan sarana prasarana pelatihan, namun ada beberapa kendala yang dihadapi dalam memenuhi kebutuhan masyarakat, yang paling mendasar adalah kurangnya sarana dan prasarana pelatihan yang sangat menunjang terhadap keberhasilan program utamanya dalam meningkatkan skill para peserta. Upaya dalam menanggulangi kendala tersebut kami selalu melakukan yang terbaik kepada masyarakat seefektif mungkin dengan segala sumberdaya yang ada". Berikut kutipan wawancara dengan instruktur UPTD BLK Kabupaten Subang : " memang ada perubahan dari tahun sebelumnya seperti contoh yang saya ketahui peserta pelatihan yang dilaksanakan secara institusioanal yang mendaftar di tahun 2017 kurang lebih sebanyak 400 orang, dan yang termonitor dan bekerja kurang lebih baru 97 orang, dan ditahun 2018 yaitu ada 656 orang dan yang sudah bekerja atau usaha sendiri kurang lebih ada 210 orang, sehingga bisa terlihat ada sedikit peningkatan dari tahun sebelumnya walaupun masih belum mencapai target yang di inginkan, karena masih ada beberapa kendala dalam melaksanakan kegiatan pelatihan". Berikut kutipan wawancara dengan peserta pelatihan UPTD BLK Kabupaten Subang: " kendalan di setiap tahunnya selalu sama seperti kendala dalam hal instruktur menurut saya kurang, terutama saat praktek kami perlu bimbingan yang maksimal dalam melaksanakan praktek, minimal ada dua instruktur saat melaksanakan praktek namun saat ini hanya satu orang, kemudian pralatan yang kami pake saat ini juga masih kurang dan rusak sehingga tidak semuanya bisa dapat digunakan, namun walaupun seperti itu kami masih bisa mengikuti proses pelatihan 
dengan cara bergantian ". Hasil Observasi yang penulis lakukan langsung bahwa untuk meningkatkan kualitas dari berbagai segi, mereka membutuhkan waktu untuk bisa memenuhi kebutuhan masyarakat di lihat bahwa setiap tahunnya mereka berusaha mengupayakan perubahan atau peningkatan program pelatihan untuk hasil yang lebih baik lagi, namun memang benar adanya kendala yang ada menghambat para peserta untuk menjadikannya kualitas yang baik.

Bedasarkan hasil wawancara dan observasi yang penulis lakukan di UPTD BLK Kabupaten Subang berkaitan dengan putaran waktu bahwa proses perubahan pada pelaksanaan pelatihan setiap tahunnya ada peningkatan dengan melakukam peningkatan kualitas instruktur disesuaikan dengan kemajuan teknologi dewasa ini. Namun dari segi peningkatan sarana dan prasarana serta peningkatan kuantitas instruktur masih kurang. Dan apabila permasalahan tersebut di kaitkan dengan teori yang di kemukakan oleh Jerry Harbour dalam pengukuran kinerja (2009:35-36), bahwa Putaran waktu adalah waktu yang di butuhkan dalam setiap proses perubahan barang dan jasa tersebut kemudian sampai kepada pengguna konsumen. Dalam hal ini proses perubahan pada pelaksanaan pelatihan setiap tahunnya ada peningkatan dengan malakukan peningkatan instruktur disesuaikan dengan kemajuan teknologi dewasa ini sehingga hasil yang diterima oleh para peserta dapat di rasakan perubahannya. berikut :

Hasil kajian terhadap faktor Penggunaan Sumber daya dapat dijelaskan sebaga

Menurut Jerry Harbour Penggunaan sumber daya adalah sumber daya yang diperlukan dalam menghasilkan produk barang dan jasa tersebut. Berikut kutipan hasil wawancara yang penulis lakukan dengan berbagai sumber : kutipan wawancara dengan KasuBag TU BLK Kabupaten Subang: " telah saya katakan sebelumnya memang kami akui bersama bahwa Sumberdaya yang ada sekarang belum memenuhi kebutuhan, terutama instruktur PNS yang setiap tahunnya ada yang pensiun, sementara penggantinya belum ada, sarana dan prasarana pelatihan yang ada di UPTD BLK Kabupaten Subang saat ini juga ada beberapa kejuruan yang kurang memenuhi standar pelatihan hal ini dikarebakan peralatan yang ada usianya sudah cukup tua dibanding dengan kemajuan teknologi yang ada saat ini, namun hal ini tidak menjadikan kami pesimis dalam mendidik para peserta untuk menjadi terampil, berbagai upaya kami lakukan diantaranya penambahan bangunan dan mesin walaupun tidak semuanya di tambah atau di ganti, peningkatan instruktur melalui Up Grading juga kami lakukan, hal ini semua kami lakukan untuk memberikan pelayanan terbaik kepada masyarakat dibidang penyiapan tenaga kerja melalui pelatihan" . Berikut kutipan wawancara dengan instruktur UPTD BLK Kabupaten Subang: " guna meningkatkan kualitas instruktur sehingga sumberdaya yang diperluka dalam menghasilkan tenaga kerja yang baik yaitu dengan kami mengikuti Up Grading Instruktur sehingga kemampuan kami sebagai instruktur terus meningkat disesuaikan dengan kemajuan industri saat ini, namun dari segi sarana prasarana penambahannya tidak sebanding dengan kebutuhan pelatihan saat ini walaupun setiap tahunnya ada penambahan peralatan baru namun jumlahnya masih kecil". Berikut kutipan hasil 
wawancara dengan peserta pelatihan UPTD BLK Kabupaten Subang : " kami sangat senang bisa mengikuti pelatihan disini, materi yang disampaikan oleh instruktur sudah memenuhi kebutuhan pengetahuan kami yang sebelumnya tidak kami ketahui, namun saat disayangkan pada praktek kami harus bergiliran menggunakan mesin karena mesin yang kami gunakan untuk praketek jumlahnya sangat minin dan juga ada mesin yang rusak". Berikut Kutipan hasil wawancara dengan Perusahaan yang ada di Kabupaten Subang : " dikami yang memasukan tenaga kerja dari BLK udah ratusan ya, dan jika dilihat dari hasil prodak BLK sama pendaftar langsung lebih unggul yang dari BLK karena biasanya yang dari BLK itu sudah dapat pelatihan dulu sehingga perusahaan tidak harus refreshment training karena basic training sudah diberikan oleh pihak BLK sebelum mereka masuk kesini". Bedarkan hasil wawancara dan observasi yang penulis lakukan berkaitan dengan sumber daya yang diperlukan, sarana dan prasarana pelatihan yang ada di UPTD BLK Kabupaten Subang dengan kondisi yang saat ini sangat mempengaruhi sekali terhadap sumberdaya yang diperlukan yang ditujukan kepada karyawan maupun peserta pelatihan, seperti yang sudah di jelaskan bahwa Instruktur PNS yang ada hanya ada 14 dengan masing-masing memegang satu kejuruan kecuali kejuruan Prosesing ada 5 instruktur PNS dan Instruktur Non PNS hanya ada 21 yaitu Teknik Manufaktur 3orang, Teknik Otomotif 4orang, Teknik elektronika 3orang, Garmen Apparel 4orang, Teknik las 2orang, prosesing 1orang, Teknik Listrik 2orang, dan Teknik Pendingin 2orang. Disini terlihat bahwa yang lebih banyak yaitu instruktur Non PNS, sehingga instruktur dan peserta mengeluhkan kurangnya sarana dan prasarana pelatihan yang ada,npada sisi lain kurangnya kuantitas instuktur yang ada saat ini berdampak pada kegiatan yang dilakukan padahal diketahui bahwa perusahaan lebih senang menggunakan tenaga kerja lulusan dari BLK karena mereka tidak perlu lagi refreshment training karena basic training sudah diberikan oleh pihak BLK sebelum mereka terjun kelapangan.

Apabila permasalaan tersebut dikaitkan dengan teori yang dikemukakan oleh Jerry Harbour dalam pengukuran kinerja (2009:35-36), bahwa Penggunaan Sumber Daya adalah sumberdaya yang diperlukan dalam menghasilkan produk barang dan jasa tersebut. Maka dari itu penggunaan sumber daya instruktur berkaitan dengan sumber daya yang diperlukan, sarana dan prasarana pelatihan yang ada di UPTD BLK Kabupaten Subang dengan kondisi saat ini sangat mempengaruhi sekali terhadap sumberdaya yang diperlukan, yang ditujukan kepada karyawan maupun peserta pelatihan.

Hasil kajian terhadap faktor Biaya dapat dijelaskan sebagai beriktu :

Menurut Jerry Harbour Biaya yang diperlukan. Ukuran ini merupakan suatu ukuran yang menitiberatkan pada hitungan per unit dasar, penggunaan satuan biaya perhari pelatihan dalam beberapa kasus walaupun organisasi memiliki banyak informasi secara total biaya namun mereka sebenarnya mereka punya keterbatasan biaya perunit. Berikut kutipan hasil wawancara yang penulis lakukan dengan berbagai sumber : Kutipan wawancara dengan Kasubag UPTD BLK Kabupaten Subang : " Nyambung dengan pertanyaan sebelumnya bahwa secara finansial cukup, karena 
disesuaikan dengan pelaksanaan kegiatan yang dilaksanakan namun yang sudah saya katakan sebelumnya untuk sarana dan prasarana pelatihan masih kurang, mengingat kondisi sarana dan prasarana yang ada sekarang banyak yang rusak karena usianya sudah lama perlu dilakukan revitalisasi, dan dana dari pemerintah menyesuaikan kegiatan yang dilaksanakan.". Kutipan wawancara dengan petugas teknis Operasional UPTD BLK Kabupaten Subang : " disesuaikan saja dengan kegiatan pelaksanaan yang ada, karena kami sudah berusaha semaksimal mungkin untuk memenuhi kebutuhan masyarakat." Kutipan wawancara dengan para peserta pelatihan UPTD BLK Kabupaten Subang: " kami tidak mengetahui masalah biaya namun yang di perlukan untuk mendapatkan biaya dari pemerintah itu menurut kami di bagian sarana dan prasarana di bagian mesin bubut karena yang kami lihat benar-benar mesin yang ada hanya bisa di hitung dan juga ada yang rusak yang bisa di pakepun itu mesin keluaran tahun 1098an sehingga menurut kami harus di ganti kalopun tidak diganti setidaknya ada penambahan mesin". Observasi yang penulis lakukan, melihat pelaksanaan pelatihan di UPTD BLK Kabupaten Subang bahwa memang benar banyak kejuruan yang kekurangan sarana dan prasarana termasuk kejuruan manufaktur mesin yang ada hanya ada 7 yang satunya rusak sehingga mereka prakteknya harus bergantian.

Bedasarkan hasil wawancara dan observasi yang penulis lakukan berkaitan dengan biaya, biaya yang di perlukan adalah untuk sarana dan prasarana dan juga SDM nya yang ada di UPTD BLK Kabupaten Subang karena kondisi yang ada saat ini tidak memadai sehingga sangat mempengaruhi kualitas tenaga kerja yang di hasilkan. Jika di gambarkan mengenai Anggaran, bahwa anggaran untuk pelatihan itu ada yang dari dana APBD dan APBN, dari dana APBD yaitu berdasarkan Renstra (Rencana Strategis) yang ada di dinas berupa rencana strategis per lima tahun yang disesuaikan dengan berapa jumlah kebutuhan pelatihan pertahunnya, sehingga harus terpenuhi target dalam kurun waktu lima tahun. Kemudian BLK juga harus menyusun RKA (Rencana Kerja Anggaran) untuk mengajukan anggaran yang akan di ajukan ke daerah kemudian setelah itu Bupati mengajukan anggaran misal tahun 2019 dengan jumlah anggaran yang sudah ditentukan untuk seluruh kegiatan pelatihan di Kabupaten Subang sebesar kebutuhannya sehingga dapat menjelaskan untuk rincian apa saja yang akan di pakai, setelah jadi diajukan kembali ke Pemda untuk di cetak DPA atau anggaran yang sudah tertera selama satu tahun. Setelah selesai kita menjalani kegiatan di bagi untuk membeli keperluan sebagai pertanggung jawaban seperti membeli atk, baju dll, jika kita ingin mengajukan anggaran sarana prasarana kita ajukan oleh RPJP selama lima tahun ini ada rencana untuk anggaran sarana prasarana. Tentu kita lihat dulu kondisi keuangan daerah beda-beda kegiatan beda DPA, pada program kegiatan didalamnya ada program pelatihan berbagai kejuruan yang sudah diajukan di Renstra RPJP.

Apabila permasalahan tersebut dikaitkan dengan teori yang dikemukakan oleh Jerry Harbour dalam pengukuran kinerja (2009:35-36), bahwa Biaya yang diperlukan dalam kegiatan yang dilaksanakan, Ukuran ini merupakan suatu ukuran yang menitiberatkan pada hitungan per unit dasar, penggunaan satuan biaya perhari pelatihan dalam beberapa kasus walaupun organisasi memiliki banyak informasi secara 
total biaya namun sebenarnya mereka punya keterbatasan biaya perunit. Seperti yang sudah dijelaskan bahwa untuk membeli satu perunit mesin saja bisa sampai dengan ratusan juta sehingga untuk mendapatkan peralatan yang dibutuhkan peserta anggaran yang didapatkan menyesuaikan kondisi keuangan daerah.

\section{Kesimpulan}

Beberapa pokok hasil penelitianini bahwa wa Efektivitas Pelatihan pada UPTD BLK Kabupaten Subang belum sepenuhnya memenuhi kebutuhan peserta diklat. Sebagaimana telah diuraikan dalam penjelasan di BAB sebelumnya. Hal ini menunjukkan bahwa dalam dimensi Produktivitas yang merupakan cerminan Kemampuan organisasi dalam menghasilkan barang dan jasa yang di tuntut oleh lingkungan masih kurang. Selain itu dapat diketahui bahwa UPTD BLK Kabupaten Subang pada tahun 2018 tidak semuanya peserta pelatihan yang mendaftar dapat mengikuti pelatihan kerja dikarenakan kurangnya sarana dan prasarana pelatihan dan keterbatasan anggaran biaya pelatihanngnya sumber daya manusia dalam hal ini tenaga Insruktur yang dapat mengakibatkan turunnya kuantitas dan kualitas tenaga kerja yang mengikuti pelatihan di UPTD BLK Kabupaten Subang. Dalam hal ini Kualitas pemproduksian barang dan jasa yang di hasilkan cukup memenuhi dunia industri karena kompetensi yang mereka punya memiliki standar kebutuhan perusahaan, namun pada beberapa kejuruan lain masih belum bisa memenuhi standar kebutuhan perusahaan karena kurangnya atau tidak sesuainya kondisi peralatan yang ada dibanding dengan peralatan di perusahaan, dan hal ini berdampak terhadap kuantitas dan kualitas penempatan tenaga kerja yang telah mengikuti pelatihan. Sehingga Ketepatan waktu yang di perlukan dalam menghasilkan barang dan jasa bahwa pelatihan yang dilaksanakan secara institusional sudah sesuai dengan kejuruan yang di ambil maka estimasi waktunya berbeda-beda namun tepat waktu. Dalam siklus pengukuran waktu untuk bisa memenuhi kebutuhan masyarakat mereka membutuhkan waktu dan proses untuk perubahan pada pelaksanaan pelatihan, bahwa setiap tahunnya ada peningkatan dengan melakukan peningkatan kualitas instruktur yang di sesuaikan dengan kemajuan teknologi, mereka berusaha untuk mengupayakan perubahan atau peningkatan program pelatihan untuk hasil yang lebih baik lagi. sehingga Penggunaan Sumber daya yang di perlukan dalam menghasilkan produk barang dan jasa yaitu dengan sarana dan prasarana pelatihan dan juga instruktur yang ada itu sangat mempengaruhi terhadap sumber daya yang diperlukan yang ditujukan kepada karyawan maupun peserta pelatihan, Pelaksanaan Sumber daya yang di miliki UPTD BLK dalam melaksanakan pelatihan yang di laksanakan secara institusional dengan adanya fenomena bahwa Tenaga instuktur yang ada masih kurang juga sarana dan prasarana yang ada saat ini dibeberapa kejuruan kondisinya tidak sesuai sehingga pelatihannya belum menunjang sepenuhnya terhadap kurikulum. Sehingga Biaya yang diperlukan dalam menunjang keberhasilan dalam menciptakan tenaga kerja yang 


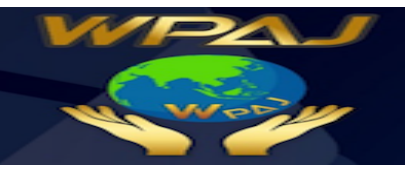

Volume 1 Issue 2, Desember 2019

https://ejournal.unsub.ac.id/index.php/publik

berkualitas dengan biaya yang di perlukan yaitu untuk sarana dan prasarana dan juga SDM nya yang ada di UPTD BLK Kabupaten Subang karena kondisi yang ada saat ini tidak memadai sehingga sangat mempengaruhi kualitas tenaga kerja yang di hasilkan, padahal banyak perusahaan yang lebih senang menggunakan tenaga kerja hasil lulusan BLK.

\section{Referensi}

A.A. Anwar Prabu Mangkunegara.2003. Perencanaan dan Pengembangan Sumber Daya Manusia. Bandung : PT Refika Aditama.

Amitai Etzioni, 1985. Organisasi-organisasi Modern, Jakarta: Suryatim UI Press

Bernard Keys dan Joseph Wolfe dalam Richard L. Daft (2011:122)

Cambel. 1989. Efesiensi dan Efektivitas Proses Perencanaan Dan Pengangguran Daerah, Jakarta: PT.Prenhallindo

Dessler, Gary.2008. Manajemen Sumber Daya Manusia . Terj. Edisi kesepuluh. Indonesia: PT Macanan Jaya Cemerlang.

Donni Juni Priansa. 2014. Perencanaan dan pengembangan Sumber Daya Manusia. Bandung: ALFABETA

Gibson, ivancevich, Donnelly. 1990. Organisasi, perilaku, struktur, dan proses, Jakarta: Erlangga

Handayaningrat Soewarno, 1994. Pengantar Studi Ilmu Administrasi dan Manajemen, Jakarta: Hj. Masagung

Handoko T. Hani, 2000, Manajemen Personalia dan Sumberdaya Manusia, Edisi II Cetakan Keempat Belas, Penerbit BPFE, Yogyakarta.

Hasibuan, Malayu S. P, 2004, Manajemen Sumber Daya Manusia, Jakarta: Bumi Aksara

Harbour, Jerry L, 2009. The Basics Performance Measurement, CRC Press is an imprint of Taylor \& Francis Group, an Informa business

Henry Simamora. 2004. Manajemen Sumber Daya Manusia. Yogyakarta: STIE YKPN.

Jones, Chales O. 1996. Pengantar Kebijakan Publik (public policy). Terjemahan Rick Ismanto. Jakarta: Penerbit PT RajaGrafindo Persada

Kurniawan. 2005. Transformasi Pelayanan Publik. Yogyakarta: Pembaruan

Lexy J. Moleong. 2007. Metodologi Penelitian Kualitatif. Bandung: PT Remaja Rosdakarya.

Mahmudi , 2015, Manajemen Kinerja Sektor Publik, Edisi ketiga, Yogyakarta: UPP AMP YKPN 
Markus Zahnd, 2006. Perancangan Kota Secara Terpadu, Erlangga. Jakarta

Mondy, R.Wayne. 2008. Manajemen Sumber Daya Manusia. Terj. Edisi Kesepuluh. Jakarta: Erlangga

Moekijat, 1991. Latihan dan Pengembangan Sumber Daya Manusia. Bandung: Mandar Maj

Noviantoro, Djatmiko. 2009. Analisis Pengaruh Pelatihan dan Pengembangan serta Kompensasi Terhadap Kinerja Karyawan Pegawai Pada PT Perusahaan dan Pengeboran London Sumatra Indonesia TBK. Medan: Tesis Tidak dipublikasikan

Price, James L, 1972. "The Study of Organization Effectiveness", Sociological Quartely, volume 13, hlm 3-15

Sikula, Andrew F. 2001. Sistem Manajemen Kinerja. Edisi Terjemahan. Jakarta: Gramedia Pustaka Utama.

Steers, R. M,1985. Efektivitas Organisasi, PPM Erlangga: Jakarta

Sudarmanto, 2015. Kinerja dan Pengembangan Kompetensi SDM. Edisi Ketiga. Yogyakarta: Pustaka Pelajar

Suharsimi Arikunto dan Cepi Safrudin Abdul Jabar, 2008. Evaluasi Program Pendidikan, Jakarta: PT.Bumi Aksara

Siagian. 2008. Manajemen Sumberdaya Manusia. Jakarta: Bumi Aksara

Sugiyono, 2009. Metode Penelitian Kualitatif Kuantitatif dan RED. Alfabeta, Bandung.

Undang-undang Nomor 13 tahun 2003 Tentang Ketenagakerjaan

UU No.23 Tahun 2014 Tentang Pemerintahan Daerah

Undang-undang Nomor 8 Tahun 2014 Tentang Pedoman Penyelenggaraan Pelatihan Berbasis Kompetensi

Zainun, Buchari, Haji . 2001. Manajemen Sumber daya Manusia Indonesia. Jakarta: Toko Gunung Agung 